\title{
Analysis of Eco-Efficiency Application to Achieve Sustainable Development
}

\author{
(Empirical Study of Wonolangan Sugar Cane Factory, Probolinggo)
}

\author{
Fanda Layla Sari*, Hesti Wahyuni, Kurnia Ekasari \\ Accounting Department, State Polytechnic of Malang \\ Malang, Indonesia. \\ *fandalayla91@gmail.com,wahyunihesti@yahoo.com, kurnia_es@yahoo.com.au
}

\begin{abstract}
This research aimed to describe the application of eco-efficiency analysis. The data analysis methods used were screening method, assessment method, cost analysis method and decisionmaking analysis method. The results of this study were the object had applied an eco-efficiency concept. The calculation of eco-efficiency ratio and eco efficiency index's results that there were fluctuation value in several periods, it were caused the differences in treatment and policy that was occurred in related years. Besides performing calculations, qualitative step was taken to determine the company's position in keeping environmental management and it was indicate that the company had carried out procedures related to environmental and linear management processes with a series of procedures eco efficiency concept.
\end{abstract}

Keywords-eco efficiency, application, environmental, management

\section{INTRODUCTION}

Eco Efficiency concept was developed by WBCSD (World based council for sustainability develop-ment) since 1992 with goals to calculate the sustainability of products and processes in short-term projects to carry out the evaluation process and make decisions specially in the factory which have a high environmental risk [1,2].

In the application of environ-mental treatment, Wonolangan sugar factory has carried out waste management such as carrying out the recycle stage by converting waste into a by-product. But it is not be used as a basis for assessing that the company has been working efficiently, especially in the running production that prioritizes environmental aspects [3]. Therefore, we need a method to identify which positioned of the company in applying concept of sustainability development which can be evaluated using eco efficiency calculations and quality analysis to review the differences of the results obtained for the existence of a policy [4].

The concept of eco efficiency informs the percentage comparison of raw materials and energy used as well as environmental impacts that occur both from an economic and physical perspective [5]. Then, after doing the eco efficiency calculation will produce information as a basis for decision making by carrying out the process of technical rearrangement, revalorize by product, product redesign, and rethink market. In calculating eco efficiency, it can be viewed from the economic and management aspects [6].

Based on these problems, it is necessary to have research that produces a method for reviewing how does the implementation of eco efficiency concept which was carried out by the manufacturing Factory. The existence assessment of eco efficiency can explain which position the manufacturing Factory is doing environmental care in its processing and support sustainability development [1].

Based on the description of the background, the identification of problem in this study is "how does the Wonolangan sugar cane factory in implementing eco efficiency concept to support sustainable development?", "Is Wonolangan sugar cane factory in accordance with the relevant rules in implementing operations?" and "what alternative can be given regarding the analysis of the problems experienced by Wonolangan sugar cane factory?"

This research aims to analysis the level of eco efficiency in Wonolangan sugar cane factory, Analysis the steps taken by Wonolangan Sugar Cane Factory in implementing several programs to support the calculation of the Eco Efficiency concept through screening methods, assessment methods, cost analysis and decision-making analysis method, analysis the motivation of Wonolangan sugar cane factory in controlling and making environmentally based decisions, analysis the process carried out by Wonolangan sugar cane factory in evaluating the calculation of eco efficiency and the form of improvement carried out after the eco efficiency assessment and analysis the efforts made by Wonolangan sugar cane factory in supporting sustainability development are reviewed through the application of the eco efficiency concept.

\section{LITERATURE REVIEW}

Eco-Efficiency is defined as providing goods or services in a competitive manner that satisfies human needs and improves quality of life, as well as progressively focusing on reducing the ecological impact and intensity of resource use throughout the life cycle towards a level that is relatively equal to the 
carrying capacity of the earth [7]. Eco-efficiency can be described in the following equation:

$$
\text { Eco-efficiency }=\frac{\text { Product or Service value }}{\text { Environm } \theta \text { antal Influence }}
$$

The application of the eco-efficiency method includes several things that the company should do to reduce the environmental impacts that occur and continue to make continuous improvement. In other rules, based on Law Number 23 years 1997, AEMP is a program of evaluating the efforts of business or activity accountability in controlling environmental pollution or damage and the management of hazardous and toxic materials [8]. AEMP (Program for evaluating the performance of a company in environmental management) is an evaluation program for efforts to be responsible for businesses and or activities in controlling environmental pollution and/or damage as well as the management of hazardous and toxic waste that is directly related to the mechanism and criteria regulated in the Regulation Minister of Environment Number 6 of 2013 [4]

\section{RESEARCH METHODS}

This research was conducted qualitative methods. The qualitative research method is a fact finding with the right interpretation to obtain in-depth data on the condition of scientific objects about a system of thought or a class of events in the present with the aim of making a systematic, factual description, picture or painting. and accurate regarding the facts, the characteristics and the relationship between the phenomena under study, where the researcher is a key instrument, data analysis is inductive/qualitative, and qualitative research results emphasize the meaning rather than generalization $[9,10]$. Data was collected through an interview process with several informants consisting of Mr. Dony Sartika as Supervisor of Human resources department, Mr. Maharyanto as Assistant manager of processing and $\mathrm{Mr}$. Nasron as head of occupational health and safety, Mr. Sutrisno as head of warehouse department, Mr. Bagus, Mr Eko Prasetyo as Manager of Quality assurance, Mr Mujiono as Technique Department, Mr Jayadi as head of finance department.

\section{RESEARCH RESULTS AND DISCUSSION}

Currently, Wonolangan Sugar Factory under PT Perkebunan Nusantara XI in carrying out the AEMP program gets an assessment position in the "BLUE" position and in terms of ISO implementation, Wonolangan Sugar Cane Factory has run the standard in operating the factory based on ISO 9000 (Quality Management System) until 2019 based on the ISO 9000 certificate that has been obtained. Based on Undangundang number 23 tahun 1997, AEMP is a program of evaluating the efforts of business or activity accountability in controlling environmental pollution or damage and the management of hazardous and toxic materials. AEMP (Program for evaluating the performance of a company in environmental management) is an evaluation program for efforts to be responsible for businesses and or activities in controlling environmental pollution and / or damage as well as the management of hazardous and toxic waste that is directly related to the mechanism and criteria regulated in the Regulation Minister of Environment Number 6 of 2013 [11].

The most influence motivations of Wonolangan Sugar Cane Factory in analyzing environmental impact and changing the perspective of factory productivity refers to ecological aspects is the existence of synergy between several components, one of which is the banking aspect in providing leeway for investment and capital procurement for industries that pay attention to aspects ecology in the process, this is referred to as sustainable financing $[12,13]$.

Not only based on the environment, all of aspects of compliance with administration and performance based on ISO are to be the most important assessments. Sustainable financing is an effort carried out by the banking industry in carrying out its business activities, especially in the provision of credit/financing and investment management by incorporating environmental risk factors into lending procedures to customers [14].

In practice Wonolangan Sugar Cane Factory has been applied the eco efficiency concept, it can be seen from the implementation of several rules based on AEMP, the efficiency of the manufacturing and the minimization of the use of resources based on natural resources and the implementation of various other activities.

In addition to the aspects of sustainable financing or a factor of funding the business, while the motivation of the main plant sugar implement process efficiencies are based environment is to consider the level of yield that later will be obtained. The Yield a level percentage of crystalline (sugar sucrose which is crystallized) compared with the total sugar cane were milled. In obtaining the level of sucrose content of sugar cane that is good is to consider the quality and the right time to harvesting sugar cane.

Because of that, there is a demand for sugar cane factory to maximize the process of production in order to be able to run efficiently and effectively so that the yield rate will good and it can support the sustainability of the plant to stay expensive aspects of ecology in minimizing the loss of time before that would happen.

The resistance in the implementation of eco-efficiency which are directly affecting the level of yield and productivity of the plant is the low of the technology when compared with technology that is used by several new factories. So the differencess in technology affect the quantity and quality of the results that have an impact on the price and profits are received by PT Perkebunan Nusantara XI. he urgency of inhibiting the sustainability of the Wonolangan sugar cane requires management to conduct operations with careful consideration to minimize future impacts, such as by optimizing environmental management

The calculation of eco efficiency based on the formula can be described was indicated that per year in 2019, the position of the company is at a point $1>$ EEI> or at 0.13 . It is 
demonstrated that the products are produced by the factory are the majority in the form of sugar, It can be said to be a product that is reasonably priced with the assumption that the burden of production is still able to be covered and losses still to be overcome, but it is very unfortunate that the process explains that each product that produced still have not been able to the burden of the environmental cost which is incurred as a result of the production or activity. So, to support that case, it takes additional charge of the party to reduce the impact of the environment and improve the availability of funds by companies.

Beside, based on the data, associated with the data previously on the value of EEI (Eco-efficiency Index) shows that the condition of factory sugar is at point $1>E E R>0$ or at 0.89 which means that the condition of the plant in the aspects of finance has not been able to cover up the existence of the impact that will happens because of environment that occurred as a result of the production process.

The process of identifying the implementation of eco efficiency can be assessed through several assessment indicators that can be described as follows: screening method, this method can be done when doing the planning of production through the identification of the quality of raw materials, fuel, the readiness of the machine production and the determination of standards of waste are excluded.

The next step was assessment method, with explains the assessment and monitoring instrument carried out by Wonolangan sugar cane factory in monitoring plant productivity and processes related to environmental impacts that occur. Stage assessment is done by analyzing the quality of the products main are produced.

Then it was continued with do cost analysis, this method is done by comparing the cost of production which is expected to power in order that may be given by several alternative design product that has been designed.

When Wonolangan sugar cane factory perform optimization by adding machine boiler, then the usage of electricity for the plant automatically will also participate optimally, so they don't have to use the electricity sources by The State Electricity Company, it is accordance with the data regarding the use of electricity which is experiencing a decline from the year 2018 to the 2019 by $11 \%$. It is inversely proportional to the decrease in the amount of water discharge in the year 2018 to the year 2019, the decline is already anticipated by implementing a system of recycling water or water treatment to reduce the use of water in the system production, so that the problems associated with lack of water received by the plant because of its availability should be divided by the farmer about to face.

The eco efficiency scenario which was initially motivated by the quality demands of the yield that must be produced in the end led to savings in natural resources and energy that are in line with the eco-efficiency function. Application of scenario is also helping finance of Wonolangan sugar cane factory in doing suppression costs and increase the amount of profit that is earned. It is as linear with reports financial that experienced an increase in earnings from the year 2018 to the 2019 by $198 \%$.

Then, the last step was decision making method analysis which is in the implementation of eco-efficiency due to be the beginning of the change. Decision making is the full right of the owner of the company. However, if needed decision making can be assisted by consultants to speed up the process. The decisions taken will be adjusted by the magnitude scale of priorities of the plan and the ability of financial companies.

At Wonolangan sugar cane factory, the entire component structure of the work that is owned by Wonolangan sugar cane factory implement a system of culture that is synergistic, integrity, and prioritize the performance of professionals.

Based on the characteristics of the organization through culture and ability to source power of man can be concluded that the aspects of decision -making that is done by the factory sugar Wonolangan as linear and can support the implementation of eco- efficiency is based on five factors main that influence decision-making: 1) information that known about the problem that is encountered, 2) level of education, 3) personality, 4) coping (in case this could be the experience of life that is associated with the experience to adapt to the conditions or urgency that occur), and 5) culture or a culture of enterprise.

The activity has been doing and related with the followprocess measurement of eco-efficiency are re-engineering process, it is conducted by Wonolangan sugar cane factory one of them is Water Treatment. The water which obtained from wells then filtered up in advance, because of that the garbage contain can be restrained and it does not hamper the process of the next. It is complete by stick iron to cleaning up. Furthermore, the water that has been filtered then precipitated by the method of sedimentation with help of coagulants and flocculants in the tank. This process can eliminate the salts of the metal by using the aeration method. This water will be flowed through pipes to the water treatment plant (WTP) and anion exchange (base receipt).

The second is Administration Comp-liance. In doing the process started since June 2017, Wonolangan sugar cane factory has been the focus of improvement the quality of the plant by applying the various requirements of administrative which support the safety work and as a form of in come and maintain the environment. As things are done is the first to perform the procedure briefing and explanation in detail first advance about K3 (Health and Safety Work) are performed every morning before employees perform activities both within the plant and the section office.

And the third is waste utilization Wonolangan sugar cane factory in the running process generates several types of wastes that require handling of special before do discharge into the environment. Waste can be categorized into solid, liquid, gas waste and the material hazardous and danger toxic. 
One of the efforts in support the development of sustainable is to put a balance between the three aspects, namely economic, environmental life, social as well as implemented into the business that is oriented on profit, people and planet that is supported by the system to manage the good (good corporate governance). In support of sustainable development, as for some of the things that must be done is to perform monitoring and improfisasi associated with the achievement of the indicators of development sustainable which consists of the basics of the welfare and well-being of the economy [15].

With applying eco-efficiency concept, it seeks to combine economic and material efficiency of production with the aim of sustainable development and the notion of social justice. They mention that although the eco-efficiency intends to reduce environmental degradation to a level that is sustainable, ecoefficiency indicators only give a rough picture of an urgent issue, serving better towards general sustainability of activity [16].

\section{CONCLUSION}

The results of the calculation of eco efficiency shows: 1) Based on EEI conducted calculations in 2019, it can be concluded that the company's position is to produce a product that systematically affordable but not yet able to cover costs due to environmental impacts produced or can be said to not meet the concept of sustainability conceptualized, 2) Based on EER it can be concluded that the company's position can produce a product by being able to cover the main production costs but cannot cover costs incurred by environmental impacts.

The application of eco-efficiency carried out by the Wonolangan Sugar Factory is not only done through calculations, but is implemented technically and systematically which includes a series of factory activities both administrative and processing. With this preventative steps, processing and post-evaluation stages can support Wonolangan sugar cane factory in achieving systematic sustainability development. Besides, the problems faced in analyzing the calculation of eco efficiency and implementation in the concept of management and administration are 1) there are still other problems that are more urgent to be solved, such as problems related to the procurement of raw materials, 2) lack of human resources and knowledge related to eco efficiency, 3) culture that is still inherent in factory workers related to negligence and ignoring the existing work safety rules, etc.

For the Government is by making a regulation related to administrative obligations that must be fulfilled by factories and industries related to environmental impacts generated as a basis for implementing funding (increasing the application of sustainable financing), helps the production cycle and the economy of the sugar factory not only in determining prices, but also participates in maintaining the availability of raw materials in the form of sugar by providing subsidies for farmers so that it can motivate farmers to continue their business
For the existence of Sugar Cane Factory is preventive efforts to prevent environmental impacts by applying the Eco efficiency method as a basis for identifying and continuing with qualitative treatment as a form of control related to external factors that are likely to occur.

\section{REFERENCES}

[1] P. Saling, A. Kicherer, B. Dittrich-Krämer, R. Wittlinger, W. Zombik , I. Schmidt and S. Schmidt "Eco-efficiency analysis by BASF: The method,” Int. J. Life Cycle Assess., vol. 7, no. 4, pp. 203-218, 2002.

[2] I. Rasti, J. Sari, Porwanto, and A. Hadiyarto, "Peluang Penerapan Ekoefisiensi dalam Penanganan Dampak Lingkungan Pada Industri Pengolahan Tepung Tempurung Kelapa Menuju Pembangunan Industri Hijau," Pros. Semin. Nas. Pengelolaan Sumber Daya Alam dan Lingkung., vol. I, no. September, pp. 15-22, 2012.

[3] D. Savitri and R. Vitri, "Pertanggungjawaban Perusahaan dalam Kasus Lingkungan Hidup Kewajiban Perusahaan dalam Hukum Kewajiban Pelaku Usaha," no. October, 2017.

[4] W.H. Putri and N.Y. Sari, "Eco-efficiency and eco-innovation: Strategy to improve sustainable environmental performance," IOP Conf. Ser. Earth Environ. Sci., vol. 245, no. 1, pp. 0-6, 2019.

[5] J. Seppälä, M. Melanen, I. Mäenpää, S. Koskela, J. Tenhunen, and M. R. Hiltunen, "How can the eco-efficiency of a region be measured and monitored?," J. Ind. Ecol., vol. 9, no. 4, pp. 117-130, 2005

[6] J. Vásquez, S. Aguirre, C.E. Fuquene-Retamoso, G. Bruno, P.C Priarone, and L. Settineri, "A conceptual framework for the ecoefficiency assessment of small- and medium-sized enterprises," J. Clean. Prod., vol. 237, 2019.

[7] R. Bidwell and E. Resources, "a Guide To Reporting Company Performance," Management, pp. 186-204, 2004.

[8] N. Fernando and F. Fachrurrozie, "Analysis of Economic Performance of Manufacturing Companies in Indonesia," J. Din. Akunt., vol. 9, no. 2, pp. 132-142, 2017.

[9] I.E. Nikolaou and S.I. Matrakoukas, "A framework to measure ecoefficiency performance of firms through EMAS reports," Sustain. Prod. Consum., vol. 8, no. June, pp. 32-44, 2016.

[10] E.S. Han and A. goleman, daniel; boyatzis, Richard; Mckee, "Metode Penelitian,” J. Chem. Inf. Model., vol. 53, no. 9, pp. 1689-1699, 2019.

[11] "Leaflet-ISO-14001-SML (Pusat Standarisasi Lingkungan Hidup dan Kehutanan).pdf."

[12] J. Quariguasi Frota Neto, G. Walther, J. Bloemhof, J.A.E.E. van Nunen, and T. Spengler, "A methodology for assessing eco-efficiency in logistics networks,” Eur. J. Oper. Res., vol. 193 pp. 670-682, 2009.

[13] T. Voituriez, K. Morita, T. Giordano, N. Bakkour, and N. Shimizu, "Financing the 2030 agenda for sustainable development," in Governing Through Goals: Sustainable Development Goals as Governance Innovation, 2017.

[14] M. Nurunnabi, "The impact of cultural factors on the implementation of global accounting standards (IFRS) in a developing country," Adv. Account., vol. 31, no. 1, pp. 136-149, 2015.

[15] Otoritas Jasa Keuangan, "Roadmap Keuangan Berkelanjutan di Indonesia Roadmap for Sustainable Finance in Indonesia 2015-2019," Otoritas Jasa Keuang., pp. 1-40, 2015.

[16] K. Raras, "Jurnal Sumberdaya Alam dan Lingkungan Implementas Environmental Management Accounting ( Ema ) Dalam Peningkatan Eko-Efisiensi Produksi Keramik Dinding Di Cikarang The Implementation of Environmental Management Accounting ( EMA ) in Eco- Efficiency Improv,” pp. 65-70. 